\title{
Pharmacology and Anti-infective Role of Raxibacumab: A Novel Monoclonal Antibody for the Treatment of Anthrax
}

\author{
H Singh ${ }^{1}$, S Ratol ${ }^{2}$, P Thangaraju ${ }^{3}$, S Kumar ${ }^{1}$, A Goel $^{4}$
}

\begin{abstract}
Anthrax, caused by Bacillus anthracis (B anthracis), poses a potential threat as a bioterror agent because after inhalation, the spores rapidly cause bacteraemia and toxaemia. It produces a toxin consisting of three proteins ie protective antigen (PA), oedema factor (EF) and lethal factor (LF). Protective antigen plays a central role in the pathophysiology of anthrax and offers an excellent

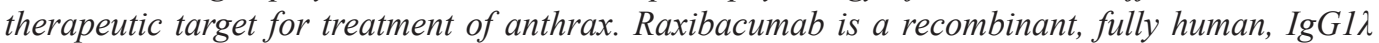
monoclonal antibody directed against PA of B anthracis. It inhibits PA binding to the anthrax toxin receptor and inhibits toxin-mediated cell death. It has been approved under animal rule or animal efficacy rule by the United States Food and Drug Administration which comes into play when it is not feasible or ethical to perform controlled clinical trials in humans. It has shown promising results in various animal studies which includes significantly improved survival rates in the raxibacumab group than non-raxibacumab group.
\end{abstract}

Keywords: Anthrax, Bacillus anthracis, raxibacumab

\section{Farmacología y papel antiinfeccioso del raxibacumab: un novedoso anticuerpo mono- clonal para el tratamiento del ántrax}

\author{
$\mathrm{H}_{\text {Singh }}{ }^{1}$, S Ratol${ }^{2}$, P Thangarajü ${ }^{3}$, S Kumar ${ }^{1}$, A Goel ${ }^{4}$
}

\begin{abstract}
RESUMEN
El ántrax, causado por el Bacillus anthracis, representa una amenaza potencial como agente bioterrorista, porque tras su inhalación, las esporas rápidamente causan bacteriemia y toxemia. Produce una toxina que consta de tres proteinas, a saber, el antígeno protector (AP), el factor edema $(F E)$, y el factor letal (FL). El antígeno protector tiene un papel central en la patofisiología del ántrax y ofrece un excelente objetivo terapéutica para el tratamiento del ántrax. El raxibacumab es un recombinante, plenamente humanoa, un anticuerpo monoclonal IgG1ג dirigido contra el AP del $B$ Anthracis. Inhibe la unión de AP con el receptor de la toxina del ántrax e inhibe la muerte celular mediada por toxina. Ha sido aprobado bajo la regla de eficacia animal de la Administración de Alimentos y Medicamentos de Estados Unidos, que entra en juego cuando no es factible o ético realizar ensayos clínicos controlados en seres humanos. Ha mostrado resultados prometedores en varios estudios con animales que incluyen tasas de supervivencia significativamente mayores en el grupo de raxibacumab que en el grupo al que no se le administra raxibacumab.
\end{abstract}

Palabras claves: ántrax, Bacillus anthracis, raxibacumab

West Indian Med J 2016; 65 (2): 358

From: ${ }^{1}$ Department of Pharmacology, AIIMS, New Delhi, ${ }^{2}$ Department of Paediatrics, PGIMER, Chandigarh, ${ }^{3}$ Central Leprosy Teaching and Research Institute, Chengalpattu, Tamil Nadu and ${ }^{4}$ Department of Paediatrics, King Edward Memorial (KEM) Hospital and Seth GS Medical College, Mumbai, India.
Correspondence: Dr P Thangaraju, Central Leprosy Teaching and Research Institute, Ministry of Health and Family Welfare, Chengalpattu, Tamilnadu, India; e-mail: drpugal23@gmail.com 


\section{INTRODUCTION}

Anthrax is caused by Bacillus anthracis which is a Gram-positive, spore-forming bacterium that usually infects herbivores. Humans are sometimes infected after exposure to contaminated animal products but anthrax poses a potential threat as a bioterror agent as seen in the 2001 anthrax attacks $(1,2)$. After inhalation, the spores rapidly cause bacteraemia and toxaemia (3). The toxin produced by this bacterium consists of three proteins ie protective antigen (PA), oedema factor (EF) and lethal factor (LF). After binding to the cell surface receptors, PA translocates the EF and LF inside the cell where they produce pathogenic effects (4). By blocking this binding, one can interfere with toxin production and this becomes a potential therapeutic strategy. This mechanism also explains the usefulness of vaccination with PA or passive immunization with anti-PA serum $(4,5)$. Initial clinical features of inhalation of anthrax are chills, nausea, fatigue and chest discomfort. Many patients present with haemorrhagic thoracic lymphadenitis, pleural effusions and sometimes haemorrhagic meningitis (6). During infection, spores are deposited in the alveolar spaces of the lungs and germinate within two to 43 days. Clinical features develop immediately after germination. Actively dividing bacilli produce three components: PA, LF and EF. The toxins cause the inhibition of normal immune system functioning and interfere with signal transduction pathways of the cells and causes cell death ultimately (6, 7). After inhalation, the spores germinate within the macrophages and lead to multiplication of the bacteria in blood, liberation of bacterial toxins, and rapidly progresses to septicaemia. Bacterial replication can be controlled by the use of antibiotics but the bacterial toxin has many deleterious effects on the body, contributing to significant mortality from the disease. The current treatment modalities (antibiotics and vaccines) are effective but they have their own limitations eg the need for 60 days of antibiotic therapy is linked with decreased compliance [during the 2001 anthrax attacks, the compliance rate was estimated to be $42 \%$ ], also drug resistant strains have been reported (8). At present, several antibiotics are effective in treatment and include: penicillin, doxycycline and ciprofloxacin. For treating inhalational anthrax, combinations of these antibiotics are used. The treating physician often starts treatment with ciprofloxacin with another drug given intravenously. The length of treatment is about 60 days because it may take spores that long to germinate. Cutaneous anthrax is treated with oral antibiotics usually for seven to 10 days. For cutaneous anthrax, doxycycline and ciprofloxacin are used (9). Although vaccination is an effective measure in preventing disease, it requires repeated administration and takes around four weeks for the development of protective antibody titres, so it is ineffective in acute illness (10). High mortality is seen when treatment is started after the onset of symptoms (11). So, there is a great need for better and compliant therapies to improve available treatment options and clinical outcomes for inhalational anthrax.

\section{Preview for anthrax in India}

The highest incidence of anthrax is reported in the South. Around 35 cases were reported in Pondicherry during 1990 to 2000. Orissa reported 42 cases [ 2 fatal] in 2002, 11 [3] in 2004,52 [6] in 2005, 19 [4] in 2006, 55 [11] in 2007, 68 [8] in 2008, 59 [3] in 2009 and 22 [0] in 2010. Around 111 outbreaks of animal or human anthrax were reported in 2007 including 10 in Orissa, 54 in Andhra Pradesh, 18 in Karnataka, 16 in West Bengal, and 12 in Tamil Nadu. Tamil Nadu reported 12 outbreaks of animal anthrax in 2007; 11 in 2008; 4 in 2009; 14 in 2010; and 4 in 2011. Approximately 182 cases of human anthrax were reported from 1953 to 2000, 0 in 1992 and 39 in 1993 (12).

\section{Protective antigen: an attractive drug target for treatment of anthrax}

The protective antigen (PA) offers an excellent therapeutic target for treatment of anthrax because it has a central role in the pathophysiology of anthrax. This target has already been explored in the form of PA-based human anthrax vaccine or purified PA (13-15) and it produces a protective immune response. Although passive immunization with polyclonal antibodies against PA has shown good response against anthrax spores $(16,17)$, monoclonal antibodies (mAbs) are better suited for immunoprophylaxis because of many advantages over polyclonal antibodies in terms of high specificity, efficacy, purity and increased safety. Many potent anti-PA mAbs have been produced by using different methods (18-20). These antibodies act by neutralizing PA by the following mechanisms: inhibition of receptor binding $(21,22)$, interference with PA heptamer formation (23), interference with LF or EF binding to PA (24), blockage of the enzymatic cleavage of PA (25), and disruption of preformed PA heptamer $(26,27)$. With the advancement of technology, it is possible to produce humanized and fully human mAbs against this target. The murine mAbs are associated with many adverse effects, particularly immune reactions, so they are usually not encouraged.

\section{What is Raxibacumab?}

Raxibacumab is a recombinant, fully human, IgG1 $\mathrm{mAb}$ directed against PA of $B$ anthracis. It inhibits PA binding to the anthrax toxin receptor and inhibits toxin-mediated cell death $(28,29)$. It has been approved under animal rule or animal efficacy rule by the United States Food and Drug Administration (US-FDA) which comes into play when it is not feasible or ethical to perform controlled clinical trials in humans (in this case the humans cannot be exposed to anthrax). The development programme for raxibacumab was designed to meet the criteria described in the "Animal Rule" which includes demonstration of efficacy in at least two animal species, evaluation of safety in humans, and pharmacokinetic data to translate the exposures in animals to recommended doses in humans $(30,31)$.

The FDA approved raxibacumab [in December 2012] (31) 
for anthracis under fast-track designation. Currently, it is indicated for:

- Inhalational anthrax in adult and paediatric patients which is preventable when alternatives are not available or inappropriate.

- Treatment of anthrax in combination with antibiotics.

\section{Mechanism of action and other pharmacological proper- ties of raxibacumab (32-35)}

The PA protein binds to its cell surface receptors [CMG2 or TEM8] and is cleaved by a membrane-bound furin-like protease leaving a $63 \mathrm{kDa}$ fragment bound to the cell. This fragment acquires a heptameric barrel structure and exposes a site on PA to which LF and EF bind with high affinity. The bound $\mathrm{EF}$ and LF proteins are then translocated from the endosome to the cytosol where they exert their toxic effects. Oedema factor is an adenylate cyclase causing oedema by altering cellular homeostasis mechanisms. Lethal factor is a zinc metalloproteinase which causes hyper-inflammatory condition in macrophages, resulting in the outburst of pro-inflammatory cytokines that contributes to the haemodynamic alterations progressing to shock and causes death of infected subjects.

Raxibacumab inhibits the effects of anthrax toxin by interfering with PA binding to its receptor. It has high affinity for PA and the binding is highly specific. In this way, it protects the subsequent cell death because neutralization of toxins liberated by $B$ anthracis can cause massive and irreversible tissue injury and death. It has been found that inhibition of PA binding by raxibacumab is a dose-dependent effect with a median inhibitory concentration (IC50) of $503 \mathrm{pM}$. It causes potent inhibition of PA-mediated induction of cAMP by $\mathrm{PA} / \mathrm{EF}$ with an IC50 of $3.5 \mathrm{nM}$ and lethal toxin mediated cell death in a dose-dependent manner with an IC50 of $0.21 \mathrm{nM}$. Raxibacumab also inhibited PA-mediated cell death in human macrophage.

\section{Pharmacokinetics}

The pharmacokinetics of raxibacumab were found to be linear over the dose range of 1 to $40 \mathrm{mg} / \mathrm{kg}$ following single intravenous administration and it was not tested at doses > $40 \mathrm{mg} / \mathrm{kg}$ in humans. At this dose in human subjects, the mean Cmax and AUCinf were $1020.3 \pm 140.6 \mathrm{mcg} / \mathrm{mL}$ and $15845.8 \pm 4333.5261 \mathrm{mcg} \cdot$ day $/ \mathrm{mL}$, respectively. The mean raxibacumab steady-state volume of distribution is more than plasma volume, showing some tissue distribution. The clearance values were much smaller than the glomerular filtration rate, indicating negligible renal clearance of raxibacumab. Because the effectiveness of raxibacumab cannot be tested in humans, a comparison of raxibacumab exposures achieved in healthy human subjects to those observed in animal models of inhalational anthrax in therapeutic efficacy studies is necessary to support the dosage regimen of $40 \mathrm{mg} / \mathrm{kg}$ IV as a single dose for the treatment of inhalational anthrax in humans. Humans achieve similar or greater systemic exposure (Cmax and AUCinf) to raxibacumab following a single $40 \mathrm{mg} / \mathrm{kg}$ IV dose compared with New Zealand White rabbits and cynomolgus macaques receiving the same dosage regimen (32-34).

\section{Dosing schedule}

Raxibacumab is given as a single dose of $40 \mathrm{mg} / \mathrm{kg}$ IV after dilution in $0.9 \%$ sodium chloride and infused over 2.25 hours. Premedication with diphenhydramine is needed within one hour prior to raxibacumab administration. This reduces the incidence of infusion-related reactions. These infusion-related reactions (rash, urticarial and pruritus) are reported during administration of the drug. For controlling the reactions, the infusion of raxibacumab should be slowed or stopped and should be treated appropriately.

Raxibacumab has been assigned to category B of pregnancy drugs. There is no adequate and well controlled studies in pregnant women. Also, animal reproduction studies are not always predictive of human response; thus, the use of raxibacumab during pregnancy should be restricted and it should be given only if clearly needed $(33,34)$.

\section{Developmental research}

In a study done on rats $(\mathrm{n}=324)$, the effects of raxibacumab versus placebo were investigated at three hours, six hours, nine hours, or twelve hours after the initiation of a 24-hour lethal toxin infusion (29). In rats receiving placebo, mean arterial blood pressure and heart rate were decreased in non-survivors when compared with those in survivors taken at six hours and then worsened with lethality first evident at eight hours [median 16 hours, range 8-152 hours]. At each treatment time, survival rates were greater for raxibacumab than for placebo but improvement was decreased at later treatment times $[p=0.001$, for the effect of time $]$. Compared with placebo, raxibacumab significantly increased mean arterial blood pressure during the 12 hours after the initiation of treatment with the greatest increase at three hours; similarly, raxibacumab significantly increased heart rate at all treatment times. The authors concluded that improvements in outcome due to raxibacumab were significant when it was administered up to six hours [and approached significance when administered up to 12 hours] after initial exposure to LeTx (29). It may be beneficial clinically when PA-mAb is administered after the onset of shock and lethality due to LeTx.

In a randomized, single-blind, placebo-controlled, doseescalation study involving 105 healthy volunteers, the safety, pharmacokinetics, and biological activity of raxibacumab were evaluated (35). Subjects received raxibacumab or placebo as a single intramuscular injection [11 subjects/cohort] or intravenous infusion [10 subjects/cohort]. Three intramuscular dose levels [0.3, 1.0, and $3.0 \mathrm{mg} / \mathrm{kg}]$ and five intravenous dose levels $[1.0,3.0,10,20$, and $40 \mathrm{mg} / \mathrm{kg}]$ were studied. In two separate intramuscular injection sites [gluteus maximus and vastus lateralis], it was observed that the drug was well tolerated with no dose-limiting adverse events. The adverse events were transient and mild to moderate in incidence and/or severity. The pharmacokinetics were found to be linear within 
each route and site of administration but were significantly different between the gluteus maximus and vastus lateralis. The mean terminal elimination half-life ranged from 15 days to 19 days. Bioavailability of PA-mAb is approximately $50 \%$ for intramuscular gluteus maximus injection and $71 \%-85 \%$ for intramuscular vastus lateralis injection. The biological activities of PA-mAb in serum were assessed using a cyclic adenosine monophosphate assay which correlated with serum concentrations. The authors concluded that this drug is safe, well tolerated, and bioavailable after a single intramuscular or intravenous dose and they supported the further clinical development as a novel therapeutic agent for inhalational anthrax.

Table: Research studies involving raxibacumab

\begin{tabular}{|c|c|c|c|}
\hline Sl.No & STUDY & EVALUATION & CONCLUSION \\
\hline 1 & $\begin{array}{l}\text { Subramanian et al. } \\
\text { A phase } 1 \text { study } \\
\text { of PAmAb, a fully } \\
\text { human monoclonal } \\
\text { antibody against } \\
\text { Bacillus anthracis } \\
\text { protective antigen, } \\
\text { in healthy volunteers } \\
\text { (36) }\end{array}$ & $\begin{array}{l}105 \text { healthy volunteers, } \\
\text { the safety, pharmaco- } \\
\text { kinetics, and biological } \\
\text { activity of raxibacumab }\end{array}$ & $\begin{array}{l}\text { Drug is safe, well } \\
\text { tolerated, and bio } \\
\text { available after a } \\
\text { single intramuscular } \\
\text { or intravenous dose } \\
\text { and they supported } \\
\text { the further clinical } \\
\text { development as a } \\
\text { novel therapeutic } \\
\text { agent for inhalational } \\
\text { anthrax }\end{array}$ \\
\hline 2 & $\begin{array}{l}\text { Migone TS, et al. } \\
\text { Raxibacumab for the } \\
\text { treatment of inhala- } \\
\text { tional anthrax (37) }\end{array}$ & $\begin{array}{l}\text { Efficacy of raxibacum- } \\
\text { ab, both as prophylactic } \\
\text { and therapeutic agent }\end{array}$ & $\begin{array}{l}\text { Single dose of rax- } \\
\text { ibacumab improves } \\
\text { survival in rabbits } \\
\text { and monkeys with } \\
\text { symptomatic inhala- } \\
\text { tional anthrax }\end{array}$ \\
\hline 3 & $\begin{array}{l}\text { NCT00639678 } \\
{[\text { HGS1021-C1063] }} \\
(38)\end{array}$ & $\begin{array}{l}\text { Evaluate the safety } \\
\text { and tolerability of } \\
\text { raxibacumab in healthy } \\
\text { subjects. }\end{array}$ & Ongoing \\
\hline
\end{tabular}

\section{CONCLUSION}

Anthrax poses a great challenge to existing healthcare system as current treatment is not satisfactory in terms of compliance and safety. Under threat of bioterrorism, we must have some alternatives which can readily control the condition. Raxibacumab works to address these serious issues and can be a good alternative to the existing therapies or it can become a part of the existing therapies [as combination] to deal with the serious situations like bioterror attacks.

\section{REFERENCES}

1. Jernigan DB, Raghunathan PL, Bell BP, Brechner R. Bresnitz EA, Butler JC et al. Investigation of bioterrorism-related anthrax, United States, 2001: epidemiologic findings. Emerg Infect Dis 2002; 8: 1019-28.

2. Inglesby TV, O'Toole T, Henderson DA, Bartlett JG, Ascher MS, Eitzen E et al. Anthrax as a biological weapon: updated recommendations for management. J Am Med Assoc 2002; 287: 2236-52.

3. Bradley KA, Mogridge J, Mourez M, Collier RJ, Young JA. Identification of the cellular receptor for anthrax toxin. Nature 2001; 414: 225-9.

4. Walsh JJ, Pesik N, Quinn CP, Urdaneta V, Dykewicz CA, Boyer AE et al. A case of naturally acquired inhalation anthrax: clinical care and analyses of anti-PA immunoglobulin G and LF. Clin Infect Dis 2007; 44: 968-71.

5. Friedlander AM, Pittman PR, Parker GW. Anthrax vaccine: evidence for safety and efficacy against inhalational anthrax. JAMA 1999; 282: $2104-6$

6. Schneemann A, Manchester M. Anti-toxin anti-bodies in prophylaxis and treatment of inhalation anthrax. Future Microbiol 2009; 4: 35-43.

7. Centers for Disease Control and Prevention. Update: adverse events associated with anthrax prophylaxis among postal employees-New Jersey, New York City, and the District of Columbia metropolitan area. MMWR Morb Mortal Wkly Rep 2001; 50: 1051-4..

8. Anthrax in health guide. NY Times; Aug 10, 2004. Available from http:// www.nytimes.com/health/guides/disease/ anthrax/overview.html.

9. Friedlander AM, Welkos SL, Ivins BE. Anthrax vaccines. Curr Top Microbiol Immunol 2002; 271: 33-60

10. Cieslak TJ, Eitzen EM. Clinical and epidemiologic principles of anthrax. Emerg Infect Dis 1999; 5: 552-5.

11. Preview for Anthrax in India. Available from http: //web. gideonline.com/ abstract. Php ? module $=$ epidemiology \& disease $=10100$ \& country $=$ G184\&view= Distribution. Last accessed August 10, 2014.

12. Clement KH, Rudge TL, Mayfield HJ, Carlton LA, Hester A, Niemuth NA et al. Vaccination of rhesus macaques with the anthrax vaccine adsorbed vaccine produces a serum antibody response that effectively neutralizes receptor-bound protective antigen in vitro. Clin Vaccine Immunol. 2010; 17: 1753-62.

13. Little SF, Ivins BE, Fellows PF, Pitt ML, Norris SL, Andrews GP. Defining a serological correlate of protection in rabbits for a recombinant anthrax vaccine. Vaccine 2004; 22: 422-30.

14. Pitt ML, Little SF, Ivins BE, Fellows P, Barth J, Hewetson J et al. In vitro correlate of immunity in a rabbit model of inhalational anthrax. Vaccine 2001; 19: 4768-73.

15. Reuveny S, White MD, Adar YY, Kafri Y, Altboum Z, Gozes Y et al. Search for correlates of protective immunity conferred by anthrax vaccine. Infect Immun. 2001; 69: 2888-93.

16. Singh Y, Ivins BE, Leppla SH. Study of immunization against anthrax with the purified recombinant protective antigen of Bacillus anthracis. Infect Immun. 1998; 66: 3447-48.

17. Little SF, Novak JM, Lowe JR., Leppla SH, Singh Y, Klimpel KR et al. Characterization of lethal factor binding and cell receptor binding domains of protective antigen of Bacillus anthracis using monoclonal antibodies. Microbiology 1996; 142: 707-15.

18. Staats HF, Alam SM, Scearce RM, Kirwan SM, Zhang JX, Gwinn WM et al. In vitro and in vivo characterization of anthrax anti-protective antigen and anti-lethal factor monoclonal antibodies after passive transfer in a mouse lethal toxin challenge model to define correlates of immunity. Infect Immun. 2007; 75: 5443-52.

19. Brossier F, Levy M, Landier A, Lafaye P, Mock M. Functional analysis of Bacillus anthracis protective antigen by using neutralizing monoclonal antibodies. Infect Immun. 2004; 72: 6313-17.

20. Albrecht MT, Li H, Williamson ED, LeButt CS, Quinn CP, Westra H et al. Human monoclonal antibodies against anthrax lethal factor and protective antigen act independently to protect against Bacillus anthracis infection and enhance endogenous immunity to anthrax. Infect Immun. 2007; 75: 5425-33.

21. Chen Z, Moayeri M, Zhou YH, Leppla S, Emerson S, Sebrell A et al. Efficient neutralization of anthrax toxin by chimpanzee monoclonal antibodies against protective antigen. J Infect Dis. 2006; 193: 625-33.

22. Migone TS, Subramanian GM., Zhong J, Healey LM, Corey A, Devalaraja $M$ et al. Raxibacumab for the treatment of inhalational anthrax. N Engl J Med. 2009; 361: 135-44.

23. Peterson JW, Comer JE, Baze WB, Noffsinger DM, Wenglikowski A, Walberg KG et al. Human monoclonal antibody AVP-21D9 to protective antigen reduces dissemination of the Bacillus anthracis Ames strain from the lungs in a rabbit model. Infect Immun. 2007; 75: 3414-24.

24. Mohamed N, Clagett M, Li J, Jones S, Pincus S, D’Alia G et al . A highaffinity monoclonal antibody to anthrax protective antigen passively protects rabbits before and after aerosolized Bacillus anthracis spore challenge. Infect Immun. 2005; 73: 795-802.

25. Vitale L, Blanset D, Lowy I, O’Neill T, Goldstein J, Little SF et al. Pro- 
phylaxis and therapy of inhalational anthrax by a novel monoclonal antibody to protective antigen that mimics vaccine-induced immunity. Infect Immun. 2006; 74: 5840-47.

26. Peterson JW, Comer JE, Noffsinger DM, Wenglikowski A, Walberg KG, Chatuev BM et al. Human monoclonal anti-protective antigen antibody completely protects rabbits and is synergistic with ciprofloxacin in protecting mice and guinea pigs against inhalation anthrax. Infect Immun. 2006; 74: 1016-24.

27. Hering D, Thompson W, Hewetson J, Little S, Norris S, Pace-Templeton J. Validation of the anthrax lethal toxin neutralization assay. Biologicals 2004; 32: 17-27.

28. Cui X, Li Y, Moayeri M, Choi GH, Subramanian GM, Li X et al. Late treatment with a protective antigen-directed monoclonal antibody improves hemodynamic function and survival in a lethal toxin-infused rat model of anthrax sepsis. J Infect Dis. 2005; 191: 422-34.

29. Animal Efficacy Rule. CFR - Code of Federal Regulations Title 21. Available from http://www.accessdata.fda.gov/scripts/cdrh/cfdocs/cfcfr/ CFRSearch.cfm?CFRPart=314\&showFR=1\&subpartNode=21:5.0.1.1.4.9. Last accessed August 10, 2014..
30. FDA approves raxibacumab to treat inhalational anthrax. Available at http:// www.fda.gov/NewsEvents/Newsroom/PressAnnouncements/ucm332341. $\mathrm{htm}$. Accessed on 11-09-2013.

31. Raxibacumab MS. MAbs. 2009; 1: 531-8. Raxibacumab. Full prescribing information. Available from http://us.gsk.com/products/assets/us_raxibacumab.pdf. Accessed on 31-08-2013.

32. Raxibacumab. Available from http://www.drugs.com/raxibacumab.html Last accessed August 10, 2014.

33. Rexibacumab (Rx). Available from http://reference. medscape.com/ drug/ raxibacumab-999792. Accessed on 31-08-2013.

34. Subramanian GM, Cronin PW, Poley G, Weinstein A, Stoughton SM, Zhong $\mathrm{J}$ et al. A phase 1 study of PAmAb, a fully human monoclonal antibody against Bacillus anthracis protective antigen, in healthy volunteers. Clin Infect Dis. 2005; 41:12-20.

35. A Study to Evaluate the Safety and Tolerability of Raxibacumab in Healthy Subjects. Available at http://www.clinicaltrials.gov/ct2/show/NCT00639678. Last accessed August 10, 2014. 